This article was downloaded by: [KU Leuven University Library]

On: 29 October 2013, At: 06: 58

Publisher: Routledge

Informa Ltd Registered in England and Wales Registered Number: 1072954 Registered office: Mortimer House, 37-41 Mortimer Street, London W1T 3J H, UK

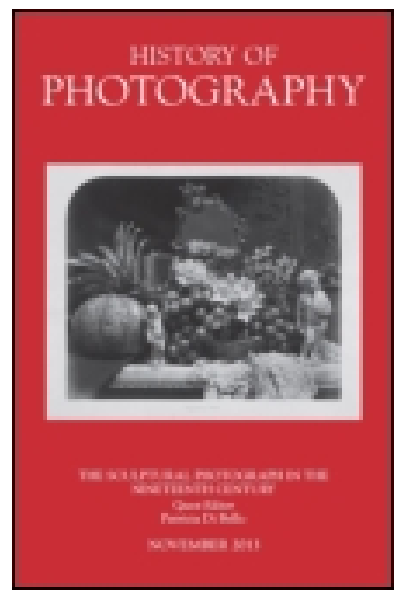

\title{
History of Photography
}

Publication details, including instructions for authors and subscription information: http:// www. tandfonline.com/loi/thph20

\section{Between Studio and Snapshot: Belle Époque Picture Postcards of Urban Statues}

Marjan Sterckx \& Leen Engelen

Published online: 28 Oct 2013.

To cite this article: Marjan Sterckx \& Leen Engelen (2013) Between Studio and Snapshot: Belle Époque Picture Postcards of Urban Statues, History of Photography, 37:4, 445-458, DOI: 10.1080/ 03087298.2013.839532

To link to this article: http:// dx. doi.org/ 10.1080/03087298.2013.839532

\section{PLEASE SCROLL DOWN FOR ARTICLE}

Taylor \& Francis makes every effort to ensure the accuracy of all the information (the "Content") contained in the publications on our platform. However, Taylor \& Francis, our agents, and our licensors make no representations or warranties whatsoever as to the accuracy, completeness, or suitability for any purpose of the Content. Any opinions and views expressed in this publication are the opinions and views of the authors, and are not the views of or endorsed by Taylor \& Francis. The accuracy of the Content should not be relied upon and should be independently verified with primary sources of information. Taylor and Francis shall not be liable for any losses, actions, claims, proceedings, demands, costs, expenses, damages, and other liabilities whatsoever or howsoever caused arising directly or indirectly in connection with, in relation to or arising out of the use of the Content.

This article may be used for research, teaching, and private study purposes. Any substantial or systematic reproduction, redistribution, reselling, loan, sub-licensing, systematic supply, or distribution in any form to anyone is expressly forbidden. Terms \& Conditions of access and use can be found at http:// www.tandfonline.com/page/terms-and-conditions 


\title{
Between Studio and Snapshot: Belle Époque Picture Postcards of Urban Statues
}

\author{
Marjan Sterckx and Leen Engelen
}

Email for correspondence:

marjan.sterckx@ugent.be, leen.engelen@soc. kuleuven.be

1 - Geraldine Johnson and Joel Snyder mention in situ photography of public sculpture, but do not delve further into the subject. See Geraldine A. Johnson, "“All Concrete Shapes Dissolve in Light”: Photographing Sculpture from Rodin to Brancusi', The Sculpture Journal, 15:2 (2006), 199-222; Joel Snyder, 'NineteenthCentury Photography of Sculpture and the Rhetoric of Substitution', in Sculpture and Photography: Envisioning the Third Dimension, ed. Geraldine A. Johnson, Cambridge: Cambridge University Press 2006, 21-34; and Geraldine A. Johnson, The Very Impress of the Object: Photographing Sculpture from Fox Talbot to the Present Day, Leeds: Henry Moore Institute 1995. 2 - The Parisian Fonds Debuisson is a private collection of picture postcards of public statues in France. See Philip WardJackson, 'Review of Roxane and France Debuisson's “À nos grands hommes”, The Sculpture Journal, 15:2 (2006), 301-3; and Marjan Sterckx, “'À nos grands hommes”: een imaginair museum van publieke beeldhouwkunst', FotoMuseum Magazine, 34 (2006), 42-5. The present article is based on the private collections of the authors, as well as the large Belfius (former Dexia) Bank collection in Brussels, which contains approximately eighty thousand postcards covering all of the Belgian communes.

\begin{abstract}
This article focuses on the photographs of public sculptures used on belle époque picture postcards of Brussels. The subject is approached from two perspectives. Firstly, we analyse the conventions of in situ photography of public sculpture in light of the genre's reliance on painterly and photographic traditions, as well as its adoption of visual strategies derived from amateur and snapshot photography. Secondly, we explore the role of the photographic mise-en-scène of picture postcards in constructing an ideological as well as visual perspective on public monuments and the cityscape. The in situ photography of urban statues for picture postcards can be regarded as a photographic genre at the intersection of documentary art reproduction practices and amateur photography of the city. Moreover, the picture postcards discussed in this essay confirm and propagate dominant discourses on the monument and the cityscape, even if at the same time such visions were challenged. In the case of Brussels, the postcards demonstrate a preference for a monumental, impressive cityscape, worthy of representing the Belgian nation and capable of legitimising it through views of sculpture as a grand art, serving the worship of grands hommes.
\end{abstract}

Keywords: Eugène Simonis (1810-82), picture postcard, monument, in situ photography, snapshot, amateur, belle époque, Brussels, cityscapes, art reproduction

Sculpture was one of the first subjects to attract photographers, as is clear from the earliest photographs by Louis-Jacques-Mandé Daguerre, Hyppolite Bayard, or William Henry Fox Talbot; and while much has been written about the relations between sculpture and photography, images taken in situ of public sculpture remain understudied. ${ }^{1}$ Photographs such as those of ancient monumental sculpture taken in Egypt by Maxime Du Camp, of (neo)gothic sculpture on French cathedrals by Henry Le Secq, or of the eighteenth-century sculptures in the parks of Versailles and the Tuileries by Eugène Atget are well known and studied. Pictures of nineteenth-century and early-twentieth-century urban statues, however, are rarely reproduced or written about in publications on photography. Yet this niche within art reproduction is found with remarkable frequency on postcards from the belle époque era (ca. 1890-1914), the golden age of the picture postcard.

Picture postcards of statues in cities and towns make possible the dissemination in space of objects that are themselves non-portable. Consequently, such postcards are still widely accessible in both public and private collections worldwide. ${ }^{2}$ They can be found for sale at flea markets, and are also digitally available on websites and in specialised online shops, forming a worldwide 'imaginary museum' (to borrow André Malraux's 1947 phrase) of public statues. Until recently, little scholarly attention had been paid to picture postcards. They are not valued as art 
or even as photography, mainly because the pictures remain for the most part anonymous, are seldom visually striking, and were made for commercial publishers. All this holds true for the specific category of picture postcards of public monuments as well. ${ }^{3}$ However, with the growth of visual and popular culture studies, postcards are beginning to receive critical attention. ${ }^{4}$

This article addresses two main questions. The first is to what extent the photographs can be said to form a genre in their own right, indebted to photographic and painterly visual traditions, but also embracing new features from amateur and snapshot photography. Secondly, we examine whether the photographic mise-en-scène to be found on picture postcards of public statues demonstrates a particular perspective on the nineteenth-century and early-twentiethcentury public monument and cityscape, via the selection, arrangement and approach the photographer takes to the subject. In other words, what can belle époque postcards of nineteenth-century public sculptures tell us about the discourse of that time on the monument, the cityscape, and the nation, and how did they contribute to it?

Next to other examples from the belle époque, we analyse a series of photographic postcards of the monument to Godfrey of Bouillon (1848) in Brussels, by the sculptor Eugène Simonis, to illustrate to what extent the photographer, in making decisions on the mise-en-scène of the photograph, was guided by usages governing the photographic reproduction of sculpture, practices from the tradition of painting, and contemporary discourse on the role of monuments in urban public spaces to visualise the nation. Simonis's centrally located, romantic-style equestrian statue - one of the first commissioned by the new nation-state of Belgium, founded in 1830 - was by 1890 a common subject for picture postcards, published individually and as part of several series. The postcards of the Bouillon monument are quite representative of in situ photography of nineteenth-century open-air statues, and thus enable us to examine different aspects of the subject. Throughout the analysis, attention will be paid to the motif (the represented subject), the mise-en-scene (the way the subject is represented), and the 'bearer' of the image (the picture postcard).

\section{The Photographic Reproduction of Sculpture}

In nineteenth-century and early-twentieth-century reproduction photography, paintings were usually framed without any context, in a manner as neutral and objective as possible, with the edges of the painting constituting the border of the image. Because of their shape and three-dimensionality, sculptures, by contrast, were necessarily reproduced against a background, and their photographers had to relate to the space around the sculpture. ${ }^{5}$ In this way, the photographer's vision of the subject permeated the image, consciously or unconsciously. Especially in the case of open-air sculpture, the photographer had a more prominent role than in the reproduction of paintings. The specific surroundings of a square, park or street contain many extra signifiers that guide our reading of the images in question. Buildings, shops, advertisements, pedestrians, carriages, tram rails, or trees constitute the biotope and backdrop of urban sculpture, enclosing it in a defined spatio-temporal frame. Even if one regards these pictures as documentary photography, in which the photographer intervenes little, the latter still had to make many decisions. ${ }^{6}$ A critical issue was the choice of the point of view - literally, as well as metaphorically - towards the monument and the urban context.

On a picture postcard of the Monument to Victor Hugo by the French sculptor Auguste Rodin, for instance, there are many other visual elements besides the monument that demand our attention, such as the surrounding architecture, a straight path, a fountain, another sculpture, and a silhouetted tree (figure 1). The latter feature occupies a central place in the composition, and stands out for its
3 - Ellen Handy discusses photographic reproductions on museum postcards as a visible sign of canon formation, but does not fully discuss their formal features. See Ellen Handy, 'Outward and Visible Signs: Postcards and the Art-Historical Canon', in Postcards: Ephemeral Histories of Modernity, ed. David Prochaska and Jordana Mendelson, University Park, PA: Pennsylvania State University Press 2010, 120-32.

4 - See also J. O. Ostman, 'The Postcard as Media', Text, 24:3 (2004), 423-42; Anne Nishimura Morse, J. Thomas Rimer and Kendall H. Brown, Art of the Japanese Postcard: The Leonard A. Lauder Collection at the Museum of Fine Arts, Boston, Boston: MFA Publications 2004; Walker Evans and the Picture Postcard, ed. Jeff L. Rosenheim, Göttingen: Steidl and New York: The Metropolitan Museum of Art 2009; Lynda Klich and Benjamin Weiss, The Postcard Age: Selections from the Leonard A. Lauder Collection, London: Thames and Hudson 2012.

5 - On the photography of sculpture, see also The Original Copy: Photography of Sculpture, 1839 to Today, ed. Roxana Marcoci, New York: Museum of Modern Art 2010; Dominique de Font-Réaulx and Joëlle Bolloch, L'oeuvre d'art et sa reproduction, Paris: Musée d'Orsay 2006; Martina Droth, 'Sculpture in the Age of Photography', Sculpture Review, 54:4 (2005), 34-6; Skulptur im Licht der Fotografie: Von Bayard bis Mapplethorpe, ed. Erika Billeter and Christoph Brockhaus, Bern: Benteli 1997; and Mattie Boom, 'Kunstreproductie', in Een nieuwe kunst: fotografie in de 19de eeuw, ed. Mattie Boom and Hans Rooseboom, Amsterdam: Rijksmuseum 1996, 85-96. 6 - See Standbeeld-Standpunt, ed. Christoph Ruys, Louvain: Uitgeverij P 2002, 2-3. 
Figure 1. Photographer unknown, publisher Electrophot, Paris, Monument to Victor Hugo by Auguste Rodin in the Garden of the Palais Royal in Paris, picture postcard, date unknown (ca. 1910). Collection of the authors.

7 - Heinrich Wölfflin, 'Wie man Skulpturen aufnehmen soll', Zeitschrift für bildende Kunst, new series 1:7 (1896), 224-8; 2:8 (1897), 294-7; and 3:25 (1915), 237-44; translated by Geraldine A. Johnson as 'How One Should Photograph Sculpture', Art History, 36:1 (2013), 52-71.

8 - No writings have been found attesting to Simonis's own view on a possible ideal viewpoint for his statue. Simonis photographed the clay model of his Godfrey of Bouillon in 1845, before it was sent to be moulded; however, this shows a mirror image of horse and horseman, with the head of the horse on the left of the picture but looking to the right. The daguerreotype is reproduced in Jacques van Lennep,

'Standbeelden en Monumenten van Brussel vóór 1914', in De Beelden van Brussel, ed. Patrick Derom and Gilles Marquenie, Brussels and Antwerp: Pandora, Patrick Derom Gallery 2000, 37.

9 - See Johnson, 'Introduction', in Sculpture and Photography, 1-19; and Tobia Bezzola,

'From Sculpture in Photography to Photography as Plastic Art', in The Original Copy, ed. Marcoci, 28-35.

10 - Diana Schulze, Der Photograph in Garten und Park: Aspekte historischer Photographien öffentlicher Gärten in Deutschland von 1880 bis 1930, Berlin: Königshausen \& Neumann 2004, 154-5.

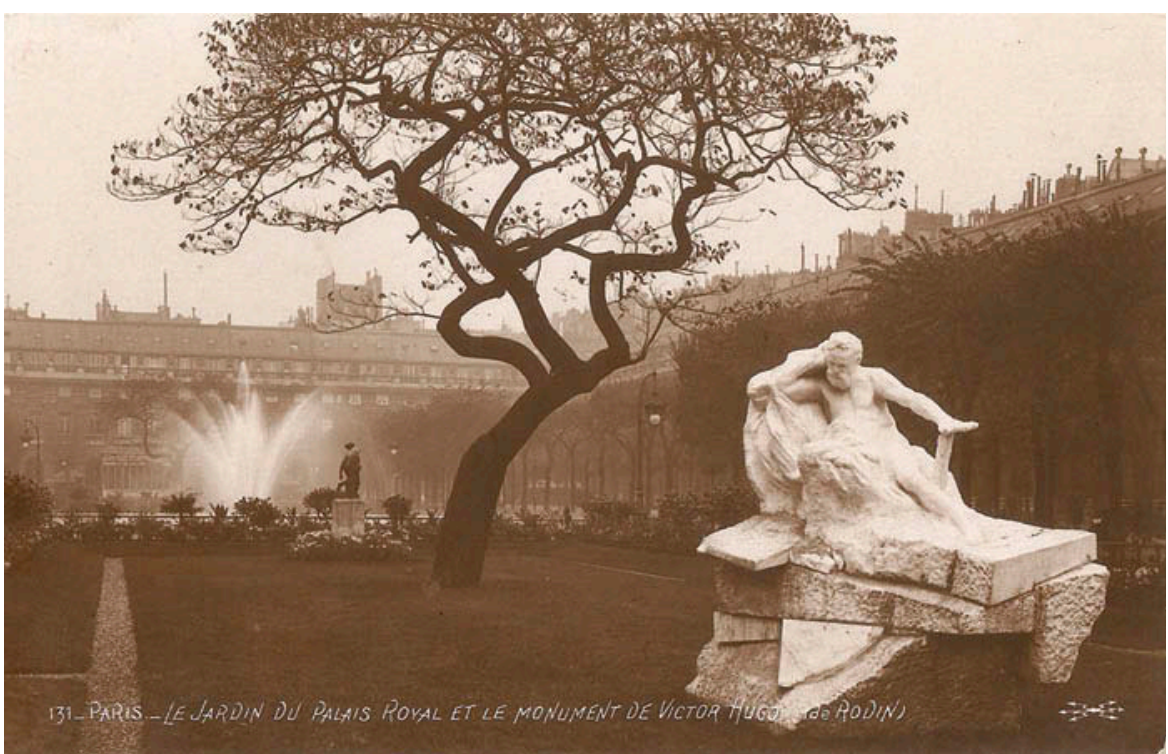

quirky, restless shape, which echoes and reinforces the troubled expression of the French writer's marble form. Numerous issues would have informed the viewpoint and framing of the scene when the photograph was taken, such as the orientation of the sculpture, the specific architectural décor, and the photographer's experience and knowledge of certain visual codes and conventions.

In three essays from this period entitled 'Wie man Skulpturen aufnehmen soll?' (1896, 1897, 1915), the Swiss art historian Heinrich Wölfflin stressed the importance of determining the ideal position from which to photograph a sculpture - namely, the viewing position originally intended by the sculptor (which of course cannot always be known). ${ }^{7}$ Wölfflin objected to the then common practice and belief that sculpture could only be 'properly' represented by a sequence of photographs from different angles, so as to overcome the obstacles facing the translation of a three-dimensional and thus spatial object into a flat image.

In the case of public statues that are not part of a building, such an ideal viewpoint does not always exist. Simonis designed Godfrey of Bouillon's statue in Brussels to be seen from all sides in an urban square. The observing public would move around and view the monument from all possible viewpoints. ${ }^{8}$ All sides of this monument have indeed some interest: while the horse's head is turned to the left, the horseman himself gazes to the right, and while his left hand holds a shield, he lifts a flag in the air with his right arm in a kind of contrapposto with the raised left leg of the horse. Whether viewed from the front, side or rear, the sculpture offers a dynamic balance between all elements. These multiple vantage points are reflected in the many photographic reproductions of the statue on picture postcards, which depict different sides of the monument as well as the surrounding buildings and streets (figure 2). When analysing them, however, it becomes clear that some viewpoints are more common than others.

Wölfflin fiercely objected to a 'painterly' (malerisch) and 'artistic' (künstlerisch) style for the photographic representation of sculpture that had been in vogue since the late nineteenth century. Some photographers were then inclined to 'interpret' sculpture in a personal, 'artistic' manner, as, for example, with Eugène Druet's and Edward Steichen's photographs of Auguste Rodin's works. Steichen's photographs at night of Rodin's Monument to Balzac serve as a clear example of such pictorial sensibilities. ${ }^{9}$ For Wölfflin, these photographic aesthetics destroyed the original appeal and effect of the depicted artwork. ${ }^{10}$

This tendency had very little impact on contemporary picture postcards, where public sculptures are usually photographed in a more neutral, descriptive and less artistic way as documents. For picture postcards, a form of commercial 


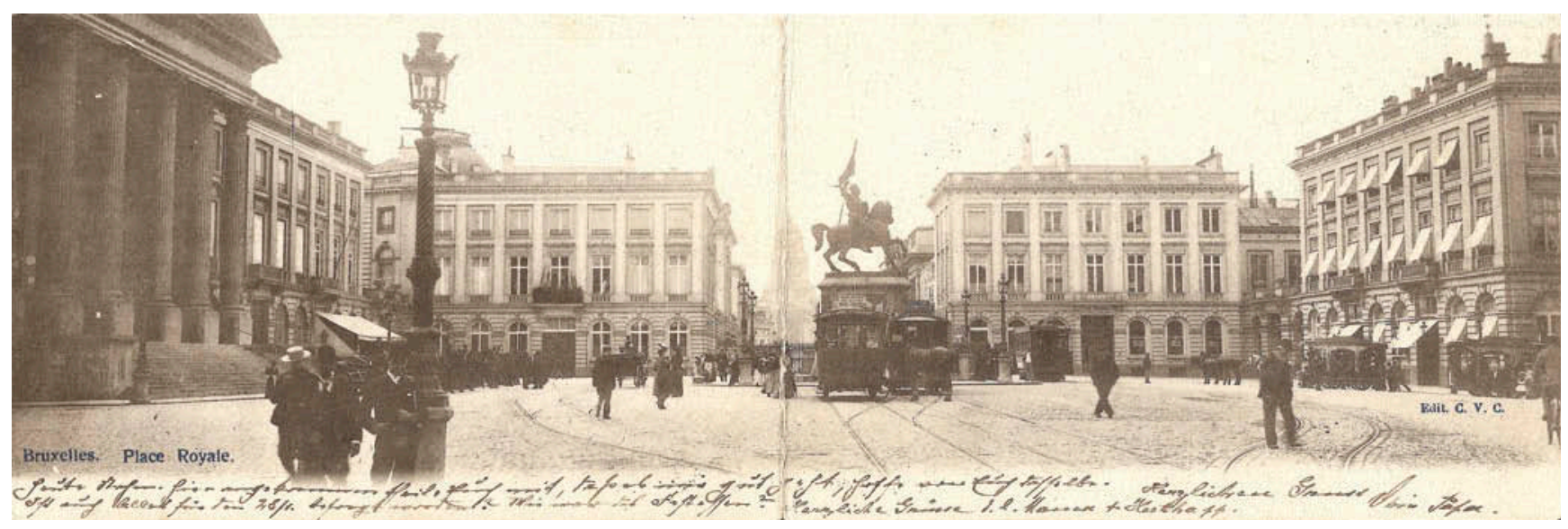

Figure 2. Photographer unknown, publisher C.V.C (Van Cortenbergh), Brussels, Place Royale/Koningsplein with the Equestrian Statue to Godfrey of Bouillon (1848) by Eugène Simonis in Brussels, panoramic picture postcard, stamped 27 January 1903. Collection of the authors.

photography, the market appeal of the subject was crucial. When the monument is the actual subject of the picture postcard, and not the square or street on which it stands, it is usually photographed in its entirety, including its pedestal, and thus from a certain distance. The monument usually occupies a central position within the image, and is taken from the front, in so far as this can be determined. The photographers seem to have sought mostly a monotone and contrasting backdrop in order to clearly outline the contours of the statue and accentuate its figure and facial features. The selection of a suitable background appears to have been as important as the orientation of the statue in determining the choice of viewpoint for the photograph.

Postcards of the Brussels Place Royale generally do not isolate the monument against a clear sky, but arrange one of the buildings in the background (figure 3). As a result, the viewer observes the statue only after the urban setting. In contrast, photographs focusing on Simonis's monument usually present the statue against a clear sky (figure 4). On a photograph of the monument for a postcard series entitled 'Pochette d'art', the actual background - the cityscape - has been completely erased in order to obtain a plain, timeless and spaceless backdrop (figure 5). A fragment of the railing reveals that the subject is actually a public monument and not a museum piece.

The characteristics of the photography of urban statues for picture postcards correspond largely to common practices in the photography of sculpture, notably the central arrangement of the object before a plain background - usually dark for white marble and stone sculptures, and light for dark bronzes (figure 6). ${ }^{11}$ Such an even, undifferentiated backdrop could be achieved either before or after taking the picture, by using portable backdrops or retouching the picture. ${ }^{12}$ This approach heightened the legibility and contrast of the images in a manner reminiscent of the longstanding practice of black-and-white engravings and lithographs of artworks. ${ }^{13}$ As a result of this practice, the object is isolated from its temporal and geographical context, enhancing its status as a timeless work of art.

Whereas in this kind of 'studio' photography the sculptural object or the portable background could be moved in order to select the ideal viewing position, this was not the case for outdoor statues. The position of the photographer was determined by the statue's fixed orientation, its surroundings and their potential for providing a suitable backdrop. This might be found, for example, in the façade of a building, the foliage of trees, or the sky (figure 7). Either cloudless or overcast grey skies provided an ideal backdrop, with diffused side lighting providing the best conditions for the depiction of public sculptures. ${ }^{14}$ The photographer thus had to position himself or herself accordingly, or return another time.
11 - A recently published photography manual still recommends photographing sculptures in situ against a monotonal and uncluttered background, such as a green lawn or a blue sky. See Inspired Photography: 189 Sources of Inspiration for Better Photos, ed. Photopreneur, Washington, DC: New Media Entertainment 2010, 106. 12 - On retouching unwanted backgrounds or using portable backgrounds, see also Magnus Bremmer and Patrizia Di Bello in this issue.

13 - On the evolution from graphic to photographic art reproduction, see Robert Verhoogt, Art in Reproduction: NineteenthCentury Prints after Lawrence AlmaTadema, Jozef Israëls and Ary Scheffer, Amsterdam: Amsterdam University Press 2007; and Snyder, 'Nineteenth-Century Photography of Sculpture'.

14 - Marcel Natkin, Pour réussir vos photos: Guide pratique de l'amateur photographe, Paris: Éditions Tiranty 1935, 24-5. 


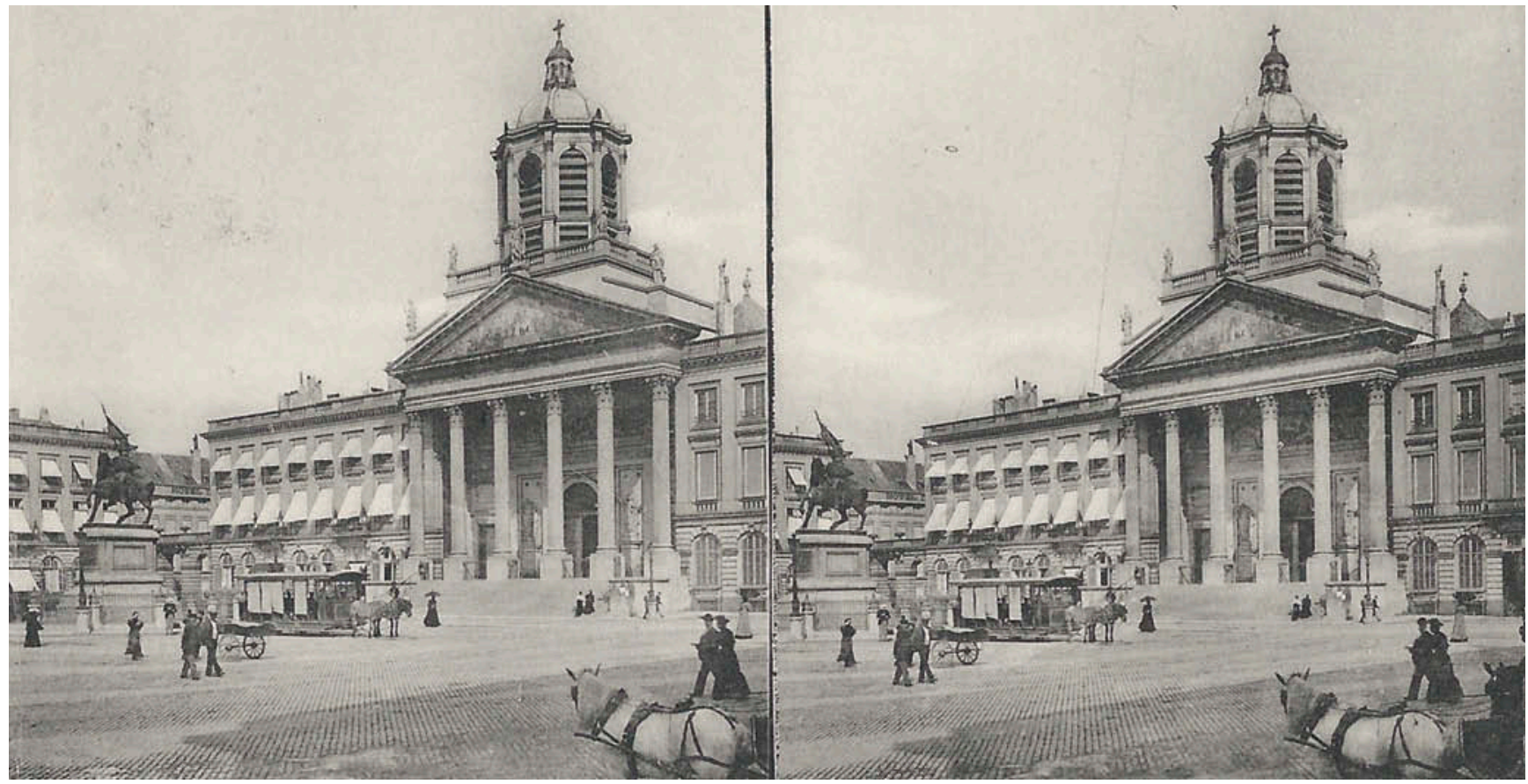

Figure 3. Photographer unknown, publisher LL, Paris, Place Royale with the St. Jacques Church and the Statue to Godfrey of Bouillon in Brussels, stereographic postcard, date unknown. Collection of the authors.

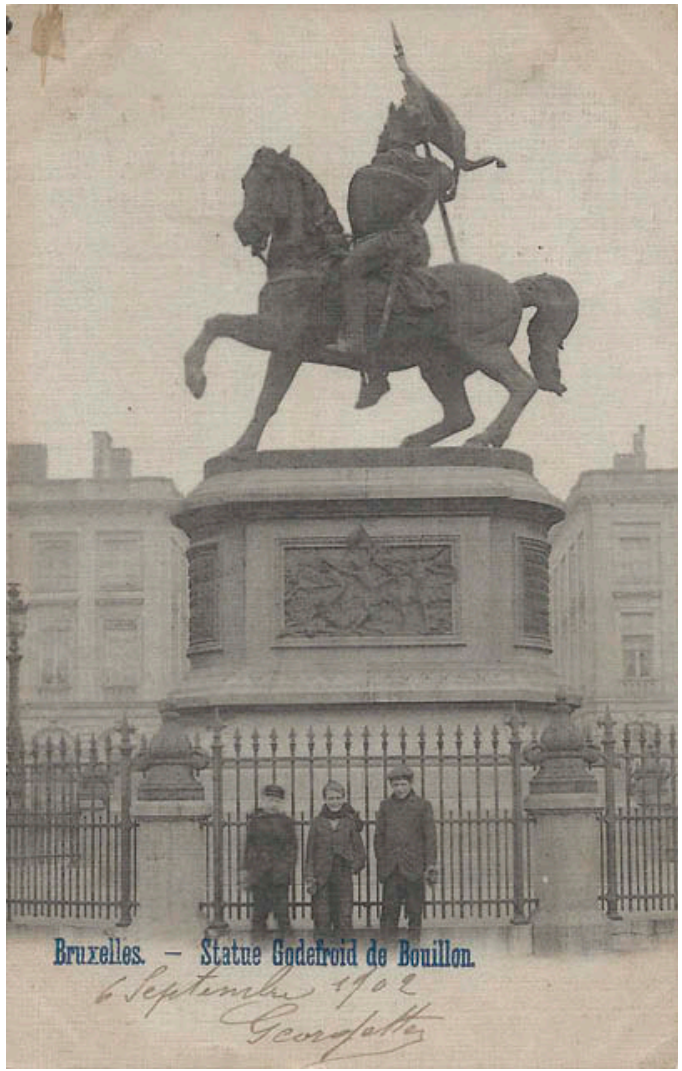

Figure 4. Photographer unknown, publisher C.V.C. (Van Cortenbergh), Brussels, Statue to Godfrey of Bouillon at the Place Royale in Brussels, picture postcard, inscribed and stamped 1902. Collection of the authors.

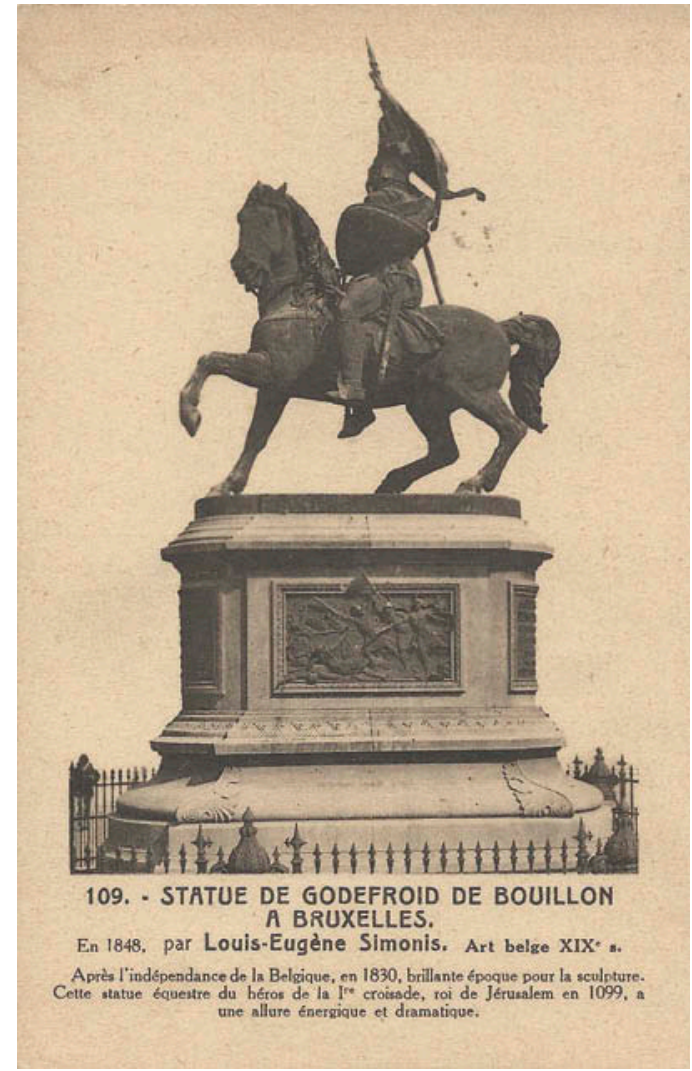

Figure 5. Photographer unknown, Statue to Godfrey of Bouillon at the Place Royale in Brussels, from the series 'Pochettes d'Art' by Prof. P. Montfort, picture postcard, date unknown. Collection of the authors. 
Here might well reside a reason for the fact that the least well represented view of Godfrey of Bouillon's statue in Brussels is that showing the face of the crusader frontally, which is somewhat remarkable from an iconographical point of view. Such a vantage point, however, required the photographer to be positioned in the northern corner of the square, looking southwards, and thereby forced to photograph the statue in contre jour (against the light). From such a standpoint it would also be more difficult to obtain an even background, as the view is cluttered by the slightly curved, narrow rue de Namur/Naamsestraat.

\section{Practices from the Painting Tradition}

Several early photographs of sculptures contain references to conventions drawn from the traditions of painting, just as many nineteenth-century and early twentiethcentury art photographs - especially landscapes, portraits and genre scenes - clearly resemble paintings. Compositions with statuettes amidst other inanimate objects, for example, can refer to the age-old genre of still-life painting, starting with Daguerre's Nature morte (Intérieur d'un cabinet de curiosités) (1837) and François-Alphonse Fortier's Nature morte (1839-40). Photographs of busts, such as Talbot's two photographs entitled Bust of Patroclus, reproduced in The Pencil of Nature (1844), refer to conventions familiar to fifteenth-century and sixteenth-century portrait painting, such as the three-quarter portrait view and a dark, even background. The position of public statues within postcard compositions may also draw on features of equestrian portrait and landscape painting.

On a more basic level, the postcard restricts the photographer to portrait or landscape formats. Unlike cityscape postcards, for which the landscape set-up is most common, picture postcards of public statues generally use the portrait format - a direction that is reinforced by the vertical orientation of most statues and their

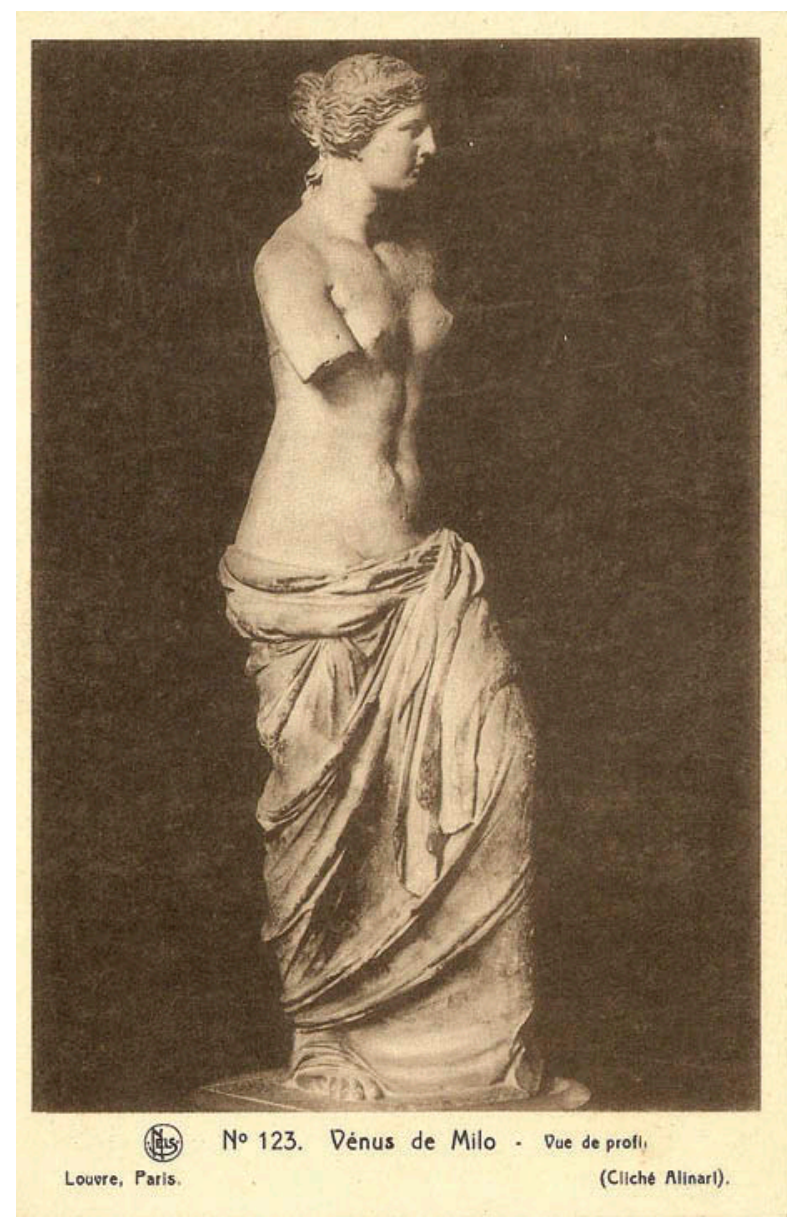

Figure 6. Fratelli Alinari, publisher Nels, Brussels, Venus de Milo, 'Art series: Louvre, Paris, nr. 123', picture postcard, date unknown. Collection of the authors. 
Figure 7. Photographer unknown, publisher Grand Bazar Anspach Editeur, Brussels, The Slave by Louis Samain at Brussels, Avenue Louise/Louizalaan, picture postcard, stamped 25 January 1907. Collection of the authors.

15 - Dirk Lauwaert, 'Stadsfotografie: De Stad, de Fotografie en de Negentiende Eeuw', Openbaar Kunstbezit Vlaanderen, 50:4 (2012), $1-40$.
16 - See Lut Pil, 'Pour le plaisir des yeux': Het Pittoreske Landschap in de Belgische Kunst, Leuven and Apeldoorn: Garant 1993; and Christine De Naeyer, 'Belgian Landscape through the Eyes of Photographic Commissions', in Darkness and Light: The Proceedings of the Oslo Symposium, ed. Roger Erlandsen and Vegard S. Halvorsen, Oslo: National Institute for Historical Photography 1995, 59-66.

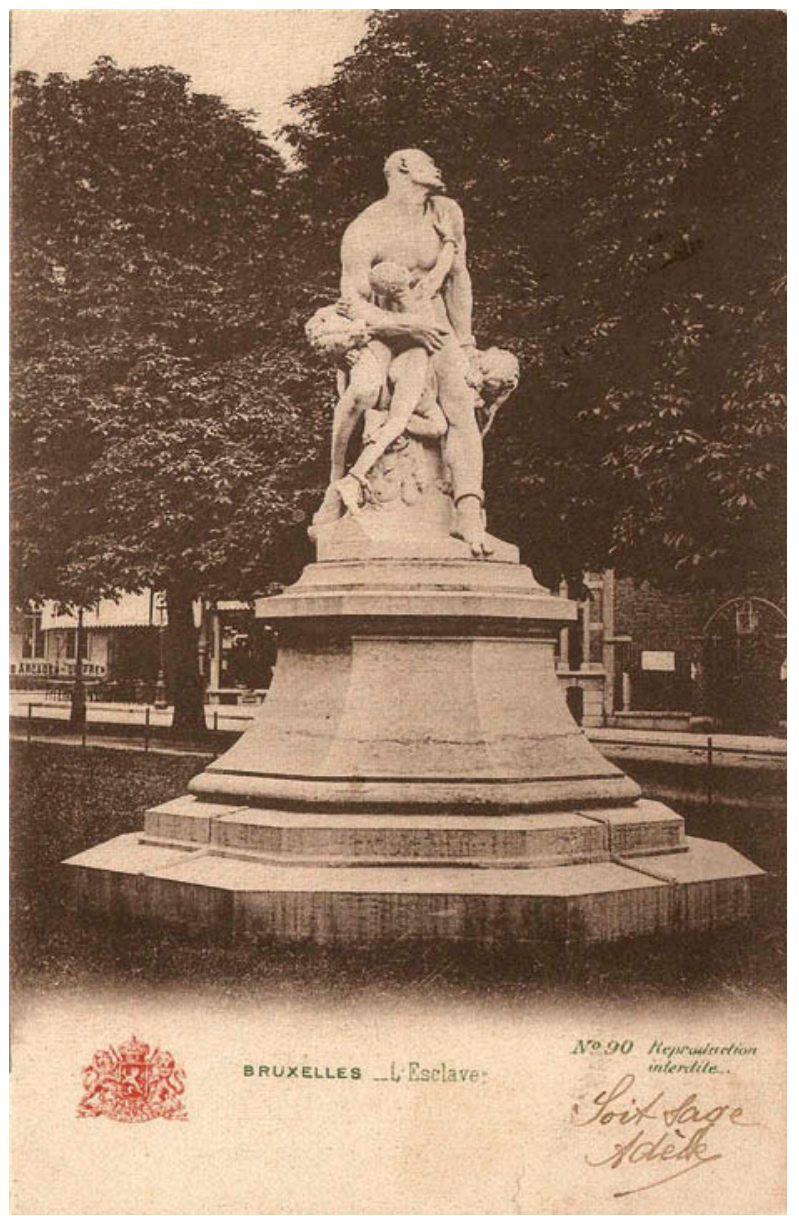

installation on plinths. Their photographs are portraits of unique, isolated monuments, demanding identification (and an artist)..$^{15}$ The landscape format is used when the surrounding urban context is emphasised, or, more rarely, for horizontally conceived monuments. Picture postcards that take the Brussels Place Royale as their subject are mostly in landscape format, whereas cards with the statue of Godfrey of Bouillon as their subject are mainly in portrait format. The latter emphasise the verticality, monumentality, uniqueness and artistry of the monument, isolating the sculpture from its surroundings in order to encourage the viewer's careful observation of the object.

Moreover, certain formulas and schemes of traditional landscape painting and city views - painted or lithographed - continue in the photography of urban statues. One of those devices is the use of a repoussoir, from the French verb meaning to push back - a motif in the foreground that serves to heighten the perspective and lead the viewer into the depth of the image. In landscape painting this is often a tree, but in picture postcards of urban statues this repoussoir is more often a passerby or the sculpture itself (figures 1,3). Another convention of landscape painting that survived was the use of a series of successive planes, as in the seventeenth-century landscapes of Claude Lorrain or Nicolas Poussin, with a foreground, a middle ground (often a lake, river or pond), and a view towards the distance. ${ }^{16}$ A post-belle époque postcard, showing a dual view of Laeken, Brussels in 1800 above and in 1933 below - demonstrates the continued prevalence of these two pictorial conventions (figure 8). This postcard juxtaposes a traditional engraved landscape view - with a tree as repoussoir on the right and a river in the middle ground - with a photograph of the same site. The compositional principles continue to inform the picture postcard, with the nineteenth-century sculptor Constantin Meunier's recently erected bronze Worker as repoussoir on the right, its contours outlined against a light sky. 


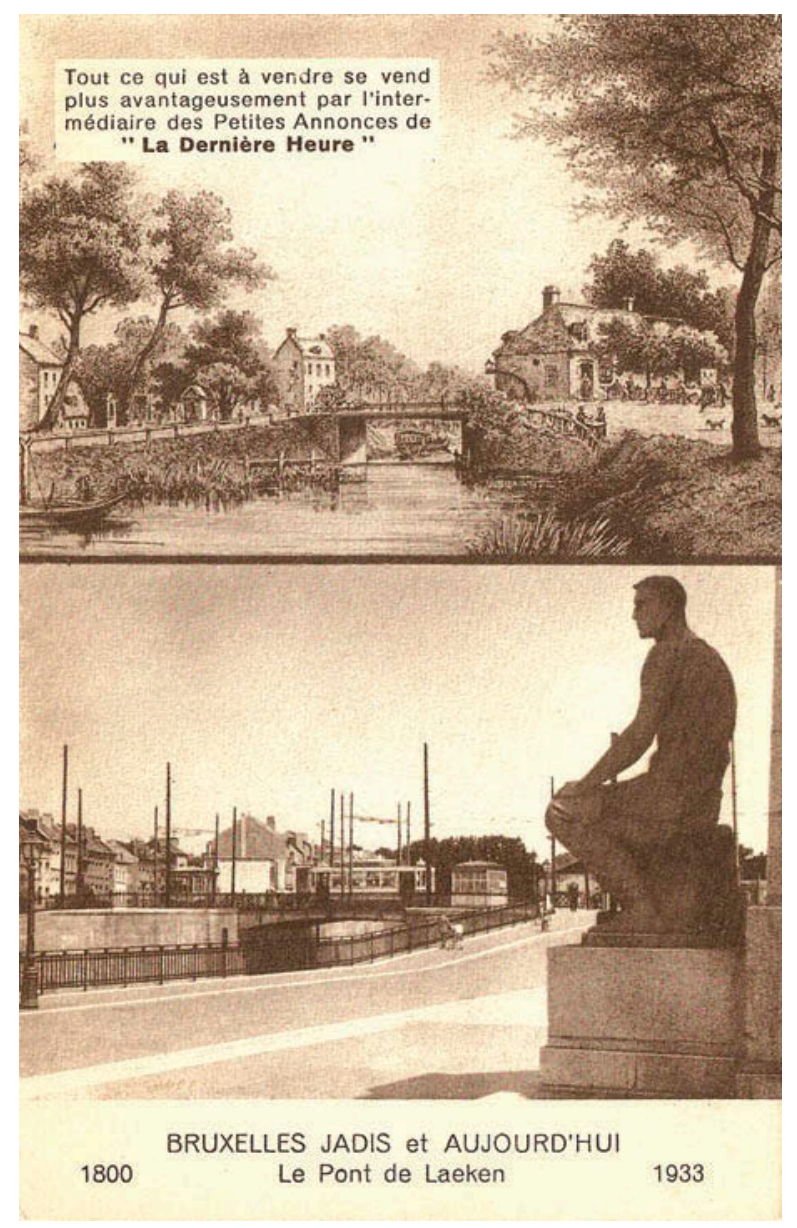

\section{The Public Monument, the Cityscape and the Nation}

As a whole, photographs of nineteenth-century and early twentieth-century public statues on postcards echo contemporary ideas on monuments. Their frequency is consonant with the contemporary phenomenon of 'statuemania' - a word coined to criticise the perceived overload of statues within the city space at the time. ${ }^{17}$ The popularity of picture postcards of statues affected their perception as well as their national and international dissemination, thus potentially increasing interest in a sculptor's work and in their location. Brussels hosted World's Fairs in 1897 and 1910, which gave rise to the production and distribution of huge quantities of postcards, showing not only the exhibition's attractions and buildings (primarily by means of drawings and collages), but also the city itself and its monuments. The popular new medium of the postcard had great social and artistic impact at the time, thanks to immense print runs, worldwide distribution, and the new medium's capacity to popularise and canonise the images it purveyed.

Picture postcards from the belle époque mainly depict academic-style statues glorifying famous men such as Godfrey of Bouillon. They always show the sculpted individual in his or her entirety, positioned on a pedestal as a hero(ine) who surpasses the more down-to-earth pedestrians. More often than not, the statue is photographed from a low angle. Even if the primary reasons for this compositional choice are the physical height of the pedestal and the desire to use the sky as a background, the effect is to magnify the aura of the represented.

These visual strategies correspond to a view of sculpture as a grand art and a means of glorifying grands hommes, even when occasionally women are represented. ${ }^{18}$ Such a vision of the monument, however, was being fundamentally challenged at this time, both in sculpture and photography. Through his planned
Figure 8. Photographer and engraver unknown, Bruxelles Jadis et aujourd'hui: Le Pont de Laeken, picture postcard, 1933. Collection of the authors.

17 - See Gustave Pessard, Statuomanie parisienne: Étude critique sur l'abus des statues, Paris: H. Daragon 1912; Maurice Agulhon, 'La statuomanie et l'histoire', Ethnologie française, VIII (1978), 145-72; and PierrePaul Dupont, "Statuomanie" et

"Bustomanie" en Belgique au XIXe siècle', Fabrique d'art: La compagnie des bronzes de Bruxelles, ed. Guy Lemaire, Brussels: La Fonderie 2003, 120-30.

18 - See, for example, the monuments to Margaretha of Austria (1849) in Mechelen, to princess Louise-Marie (1879) in Philippeville, and to Gabrielle Petit and Edith Cavell erected after the First World War in Brussels, to name but a few Belgian examples. 
19 - Nevertheless, as contemporary picture postcards illustrate, Rodin's group of Burghers was at that time still presented on a pedestal in Calais.

20 - See, for example, Natkin, Pour réussir vos photos, 68 .

Figure 9. Photographer unknown, Detail of the statue La Charité (1543-44) by Jacques Dubroeucq in the Sainte Waudru Church in Mons/Bergen, photograph, 1914-18.

Brussels, KIK-IRPA, nr. A8256. (C)

KIK-IRPA, Brussels. elimination of the pedestal, Rodin wanted The Burghers of Calais (1884-95) to stand on a par with the viewer, both literally and figuratively. ${ }^{19}$ Similar strategies of 'humanisation', decentralisation, and fragmentation of the monument could also be observed in some photographs of sculptures around this time. Photographers such as the Alinari brothers, Eugène Atget, and Eugène Druet began to represent sculptures in poignant close-ups, focusing on a particular detail or body part such as the hands or the face (figure 9). These photographers depicted public sculptures without any distance or context, sometimes making use of unusual viewpoints and dramatic lighting in order to bring dynamism to the stone or bronze.

In contrast, the monumentality of public sculptures as reproduced on picture postcards is all the more evident, especially when bystanders are included in the scene, whether as self-conscious posers or unsuspecting passersby. Animated street scenes were indeed a popular subject in photography at the time. ${ }^{20}$ The presence of bystanders enabled the viewer of the postcard to gauge the scale of the actual monument. This is particularly necessary in the case of colossal monuments, such as the stone Lion of La Gileppe (figure 10). Captions on postcards commonly mention its height of 21.50 metres and its weight of 300,000 kilograms. The persons depicted in these photographs often seem minute in comparison with their counterparts in stone or bronze on their high pedestal, underscoring the literal and metaphorical grandeur of both the represented figure and the monument, notwithstanding the small scale of the postcard itself. The presence of people in picture postcards anchors the photograph to the time and place of its production, and also reminds us that public monuments were often financed and supported by local communities.

Children are repeatedly depicted around monuments, often in little groups. In such cases, the contrast in scale is all the more striking. No doubt, children were attracted by curiosity to the camera and the photographer for whom they formed

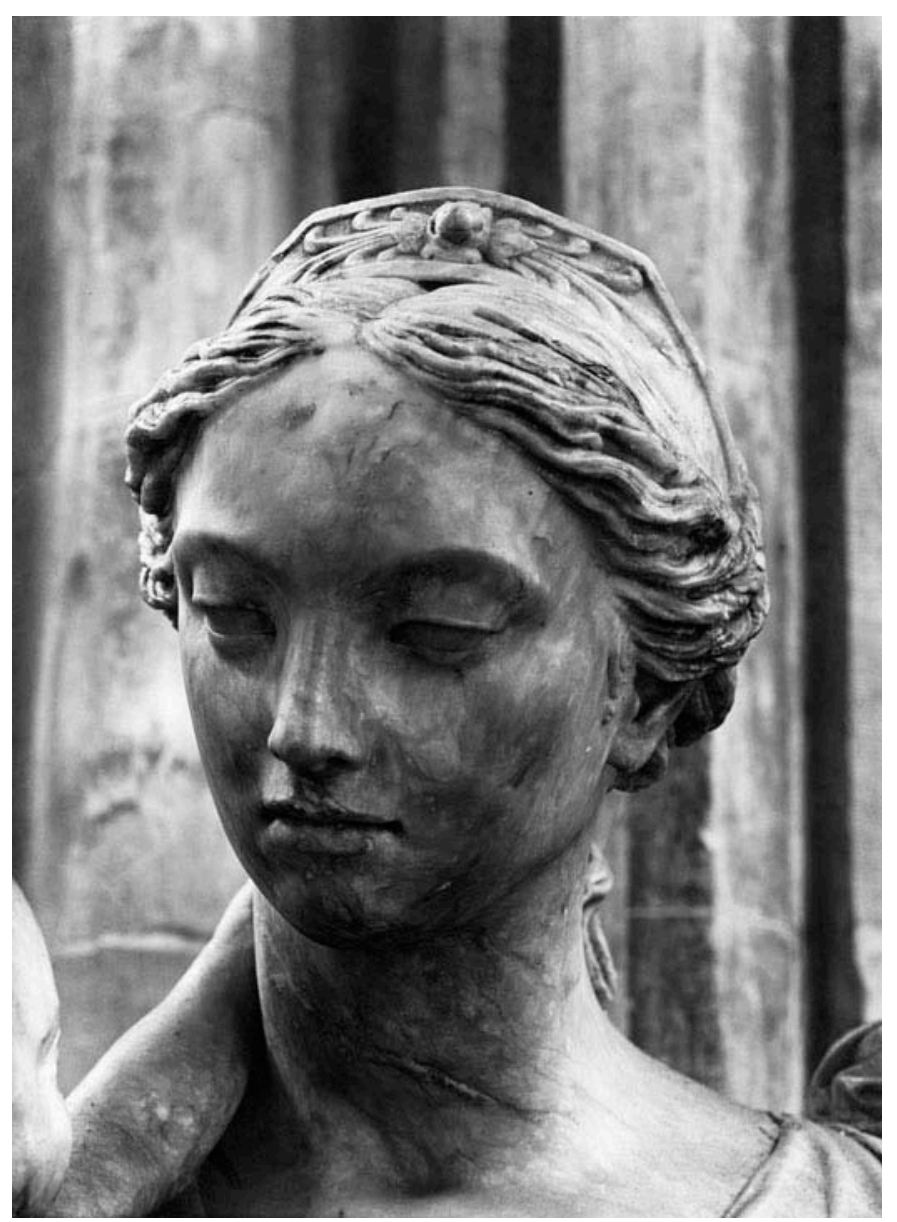




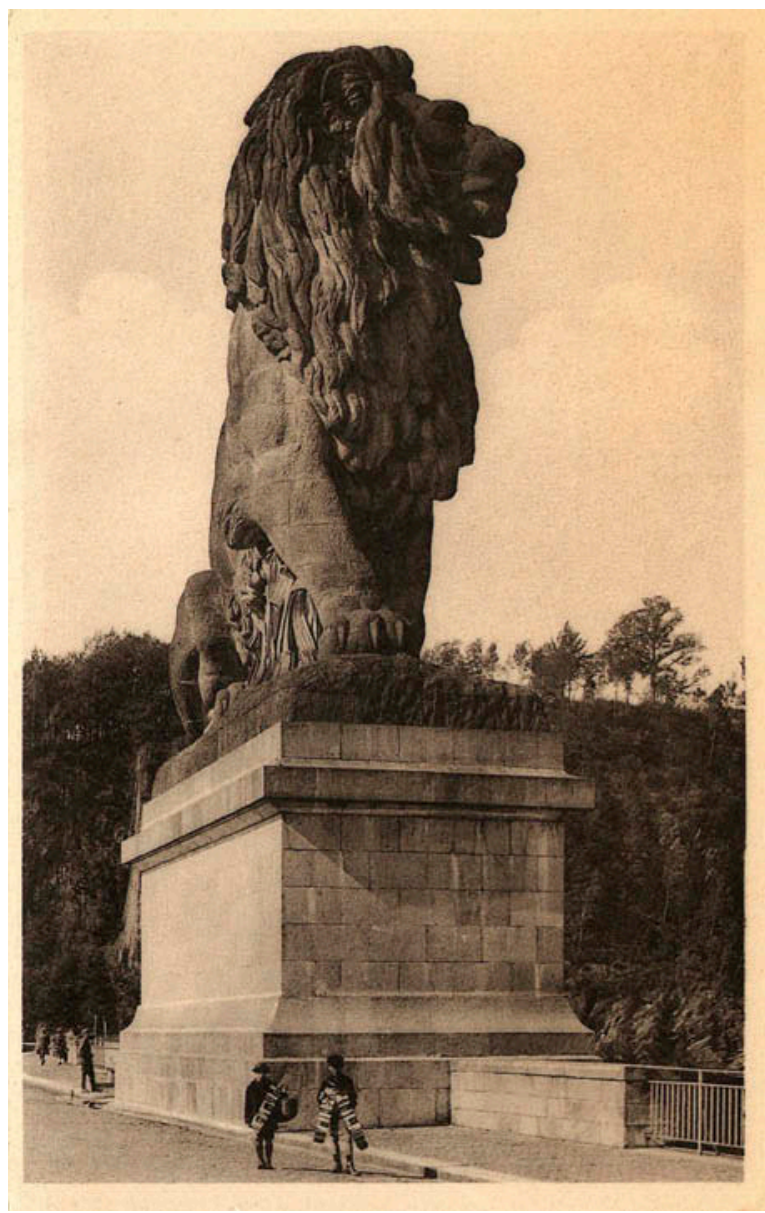

ideal photogenic extras, but the presence of children on picture postcards also strengthened the statue's educational or even moralising aspect. Picture postcards, just like the actual statues, thus functioned as exempla virtutis (examples of virtue) in the case of heroic figures, or as memento mori, reminding generations to come of the fleetingness of life or of past atrocities. ${ }^{21}$ Sometimes flowers and memorial wreaths are visible in the photographs, testifying to the monuments' role in the public celebration of heroic figures and as the site of well-attended ceremonies.

The presence of people, posing in the foreground or strolling around in the background of public statues, shifted postcard photographs away from typical studio reproductions toward the aesthetics of amateur photography. With the marketing of George Eastman's innovative and inexpensive handheld Kodak cameras from 1888 some of which could also be used to make actual picture postcards - photographs of urban statues could be taken perfectly by tourists and other amateur enthusiasts. ${ }^{22} \mathrm{~A}$ snapshot aesthetic, however, characterised by a preference for animated scenes, spontaneous expressions, informal framing and posing, fragmentation, optical distortions, blurring, and occasional focus faults, was slow to emerge. Most professional photographers continued to make use of large tripod cameras with glass plates, and many amateurs, particularly expert ones (as opposed to complete dilettantes), adhered to the conventions of art photography for sources and inspiration. ${ }^{23}$ During the belle époque, aspects of a snapshot aesthetic had fierce advocates as well as ardent adversaries. ${ }^{24}$ According to the Belgian photographer Marcel Vanderkindere, the photography of isolated monuments was a task for postcard editors, whereas amateur photographers should always photograph monuments in their context. ${ }^{25}$ Nevertheless, picture postcard photography was one of the earliest forms of professional photography to embrace, albeit tentatively, a snapshot aesthetic.
Figure 10. Photographer unknown, publisher Ernest Thill, Brussels, The Lion by Félix-Antoine Bourré at the Barrage de la Gileppe, Belgium, picture postcard, 1910. Collection of the authors.
21 - Leen Engelen and Marjan Sterckx, 'Remembering Edith and Gabrielle: Picture Postcards of Monuments as Portable lieux de mémoire', in Imaging History:

Photography after the Fact, ed. Bruno Vandermeulen and Danny Veys, Brussels: ASP Éditions 2011, 87-103.

22 - In 1903 Kodak introduced the A3 Folding Pocket Kodak, the first postcard camera. See Todd Gustavson, 'Innovative Devices: George Eastman and the Handheld Camera' and Clément Chéroux, 'A Sense of Context: Amateur Photography in the Late Nineteenth Century', in Snapshot: Painters and Photography, Bonnard to Vuillard, ed. Elizabeth W. Easton, New Haven and London: Yale University Press 2011, 12-21 and 37-45; and Rachel Snow,

'Correspondence Here: Real Photo Postcards and the Snapshot Aesthetic', in Postcards: Ephemeral Histories of Modernity, ed. Prochaska and Mendelson, 42-53.

23 - Chéroux, 'A Sense of Context'; Snow, 'Correspondence Here'; and Mark

Jarzombek, 'Joseph August Lux: Theorizing Early Amateur Photography - In Search of a "Catholic Something", Centropa, 4:1 (2004), 80-7.

24 - Joseph August Lux and Mark Jarzombek, 'Artistic Secrets of the Kodak (1908) by Joseph August Lux', Centropa, 4:1 (2004), 85-6. 
25 - Marcel Vanderkindere, 'L'art de bâtir les villes: Rôle de l'amateur photographe', Bulletin de l'Association belge de photographie, 36:1 (1909), 16-22. He mainly refers to architectural monuments here.

26 - On the crucial role of location in this matter, see Naomi Schor, "Cartes Postales": Representing Paris 1900', Critical Inquiry, 18:2 (1992), 188-244.

27 - In Brussels these include statues of Augustin-Daniel Belliard (1838) by Guillaume Geefs, Karel Van Lotharingen (1848) by Louis Jéhotte, Nicholas Rouppe (1850), Egmont and Horne (1864) by Charles-Auguste Fraikin, Frans Anneessens (1889) by Thomas Vinçotte, Charles Rogier (1897) by Guillaume de Groot, and Frédéric de Mérode (1897) by Paul du Bois and Henry van de Velde, who can all be considered founding fathers of the nation. See van Lennep, 'Standbeelden en Monumenten van Brussel vóór 1914'.

28 - Leopold II, King of the Belgians, controlled the Congo Free State in this period, from 1885 to 1908 . On the colonial history of Belgium, see David van Reybrouck, Congo: Een Geschiedenis, Amsterdam: De Bezige Bij 2010; also published as Congo: une histoire, trans. Isabelle Rosselin, Paris: Actes Sud 2012. This postcard series also included postcards of monuments to Anneessens, de Brouckère, de Jenneval, Verhaegen, and T'Serclaes.

29 - Edward John Wall, The Photographic Picture Post-card for Personal Use and for Profit, London: Dawbarn \& Ward 1906, 98-9.

30 - See also Engelen and Sterckx, 'Remembering Edith and Gabrielle'.
Several postcards of the equestrian monument to Godfrey of Bouillon, such as an example from the 'Série Bruxelles' by the publisher Nels - a series that locates the monument in a sequence of the main tourist sites of the Belgian capital - illustrate the emerging aesthetic influences of amateur street photography (figure 11). In this postcard, a tram passing in the background on the right and the pedestrians strolling along the street, some caught glancing back at the camera, add a sense of urban dynamism to the representation of the scene. The swift movement of the woman in the foreground contributes to the energy of the image and its snapshot qualities. In other cards of the same monument, the movement of people, bicycles and carriages, some partially cropped from the image, result in the blurred depiction of legs, wheels and horses' legs (figures 2, 11, 12, 13). Even where the pedestrians appear at ease near the monument, there is nonetheless a significant difference in scale between the sculpted figure and these bystanders - a disparity reinforced by the high plinth and the perimeter fence around the monument. Godfrey of Bouillon clearly appears here as a grand homme - a hero larger than ordinary mortals.

Not all statues, however, seem to have been as eligible for photographic reproduction and distribution via picture postcards. While some monuments were frequently photographed, others received little or no apparent attention in spite of their high esteem. The demand of tourists, collectors, and residents probably determined the choice of statue for picture postcards, and the commercial and strategic decisions based, for instance, on the monument's specific location within the city - of those publishers that specialised in the genre, such as Nels-Thill, Desaix, Dohmen, and Grand Bazar Anspach Editeur in Brussels. ${ }^{26}$ After Belgium gained independence in 1830, there was a concerted effort to establish a longstanding history and identity for the new nation. Literature, history painting, and public sculpture were all art forms with which to express the identity of the nation-state. In the course of the nineteenth century, several monuments to the state's grands hommes were erected and then chosen as the subject of postcards. ${ }^{27}$

An ensemble of these postcards forms a kind of photographic double of the sculptural national pantheon, as testified by the series Panthéon national by the Brussels publisher Van Cortenbergh fils, which includes Simonis's Godfrey of Bouillon (figure 14). This series had both educational and historical ambitions, with its aim being to legitimise the country before national and international audiences in times of colonialism. ${ }^{28}$ The postcard's caption not only echoes the specific focus of the series, but also guides the viewer's reading of the image. After the title identifies the subject as 'Godfrey of Bouillon, 1058-1100', a short descriptive text explains his national significance and that of the monument's site: 'Hero of the first crusade. [...] It was on a mountain not far from Brussels (maybe even the current Place Royale) that Godfrey of Bouillon called the people to follow him - Equestrian statue by Simonis 1848'. The publisher thus not only grants the current Belgian capital a longstanding and important (pre)history, but through the Panthéon national series also weaves a larger nation-building narrative, bringing unity - on paper - to the sculptural pantheon dispersed throughout the city.

Whether or not the government played a role in the selection of nationalist subjects for such postcard series is uncertain. According to an early twentiethcentury guide for photographers working, or aspiring to work, for picture postcard publishers, collectors were especially keen for subjects with an historical significance. $^{29}$ Based on their annotations, purchasers were interested in postcards of statues not so much because of the artist's reputation or the aesthetic value of the statue or the photograph, but because of the historical figure represented or its location. This criterion of acquisition is demonstrated by postcards with handwritten annotations such as 'Nous sommes à Bruxelles' (We are in Brussels). The public sent postcards to remind friends and family of their travels, or collected picture postcards of statues mainly as a mnemonic device, a souvenir or aidemémoire of the actual in situ experience of the statue, which in the case of a monument was itself an aide-mémoire of history. ${ }^{30}$ 

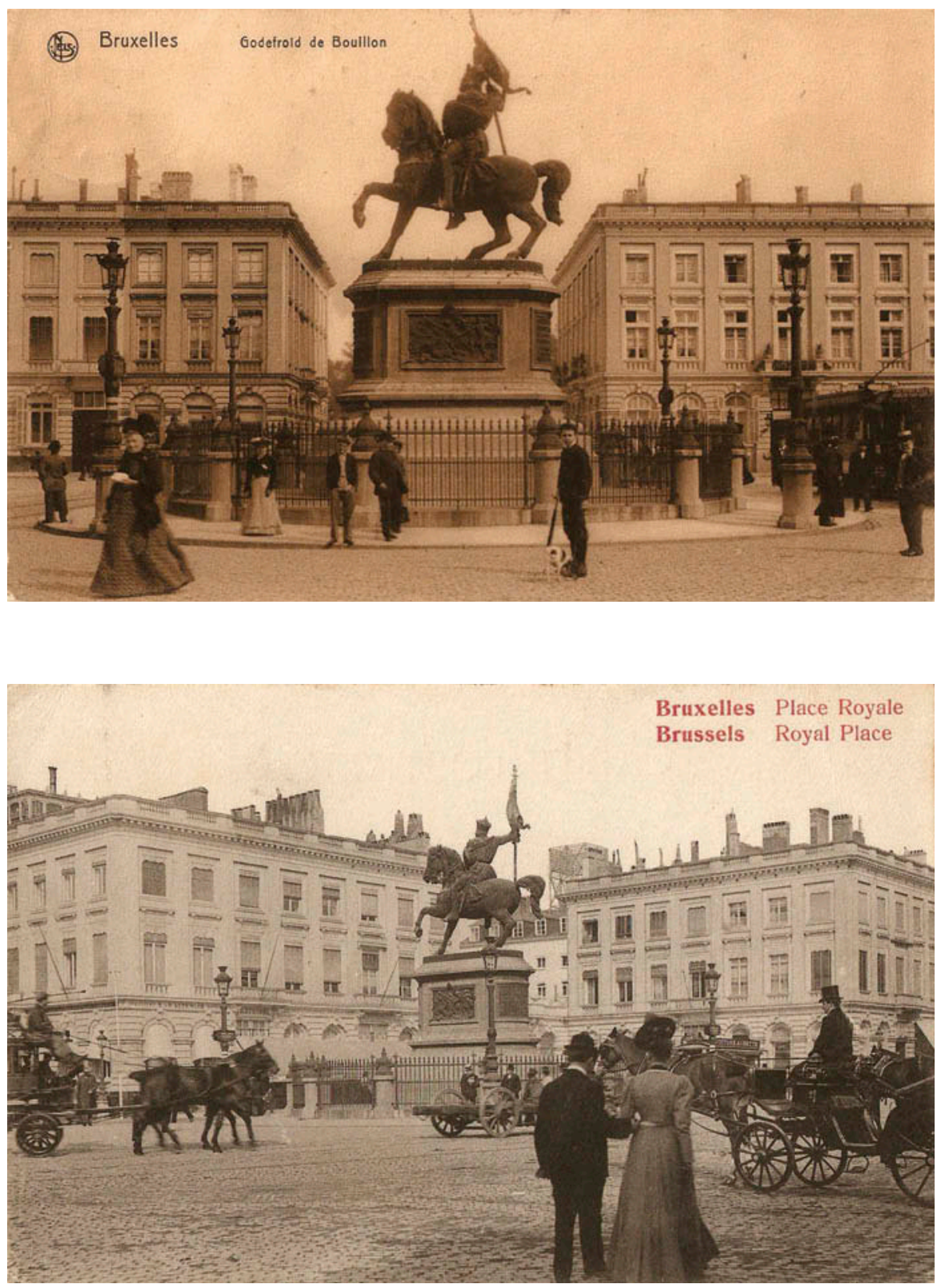

Where possible, photographers generally opted for a wide boulevard in the background in order to provide the statue with a monumental setting and the image with pictorial depth. Such visual devices, however, were dependent on the actual position and surroundings of the monument and the choice of subjects for picture postcards. The most photographed statues were of subjects endowed with a certain grandeur and considered of educational or national merit. Those statues located on the main thoroughfares of the capital and which were highly visible to tourists, those which benefited from an outstanding backdrop, whether a stunning vista or some particularly grand buildings, and those which were found in the city centre were often popular subjects for picture postcards. ${ }^{31}$

As far as Brussels is concerned, the aesthetics of photographic postcards of urban statues seems to have been dominated not so much by the late-nineteenthcentury picturesque vision of the city of Charles Buls, mayor of the city from 1881 to 1899 and author of Esthétique des villes, ${ }^{32}$ but rather by that of his predecessor, Jules Victor Anspach, mayor from 1863 to 1879 , who had so admired the urbanisation project of Paris undertaken by Napoleon III and Georges-Eugène Haussmann. Wellcomposed photographs of statues to national heroes in front of grand views of the
Figure 11. Photographer unknown, publisher Nels, Brussels, Statue to Godfrey of Bouillon at the Place Royale in Brussels, 'Serie Bruxelles n' 37', picture postcard, date unknown (after 1903). Collection of the authors.

Figure 12. Photographer unknown, publisher unknown, Statue to Godfrey of Bouillon at the Place Royale in Brussels, picture postcard, ca. 1911. Collection of the authors.

31 - See Schor, ““Cartes Postales”, 188-244.

32 - Charles Buls, Esthétique des villes, Brussels: Bruylant 1893. 
Figure 13. Photographer unknown, publisher unknown, The Place Royale in Brussels with the statue to Godfrey of Bouillon, picture postcard, stamped August 1909. Collection of the authors.

Figure 14. Photographer unknown, publisher Van Cortenbergh fils, Brussels, Statue to Godfrey of Bouillon at the Place Royale in Brussels, Serie I 'Panthéon national Bruxelles', picture postcard, date unknown. Collection of the authors.
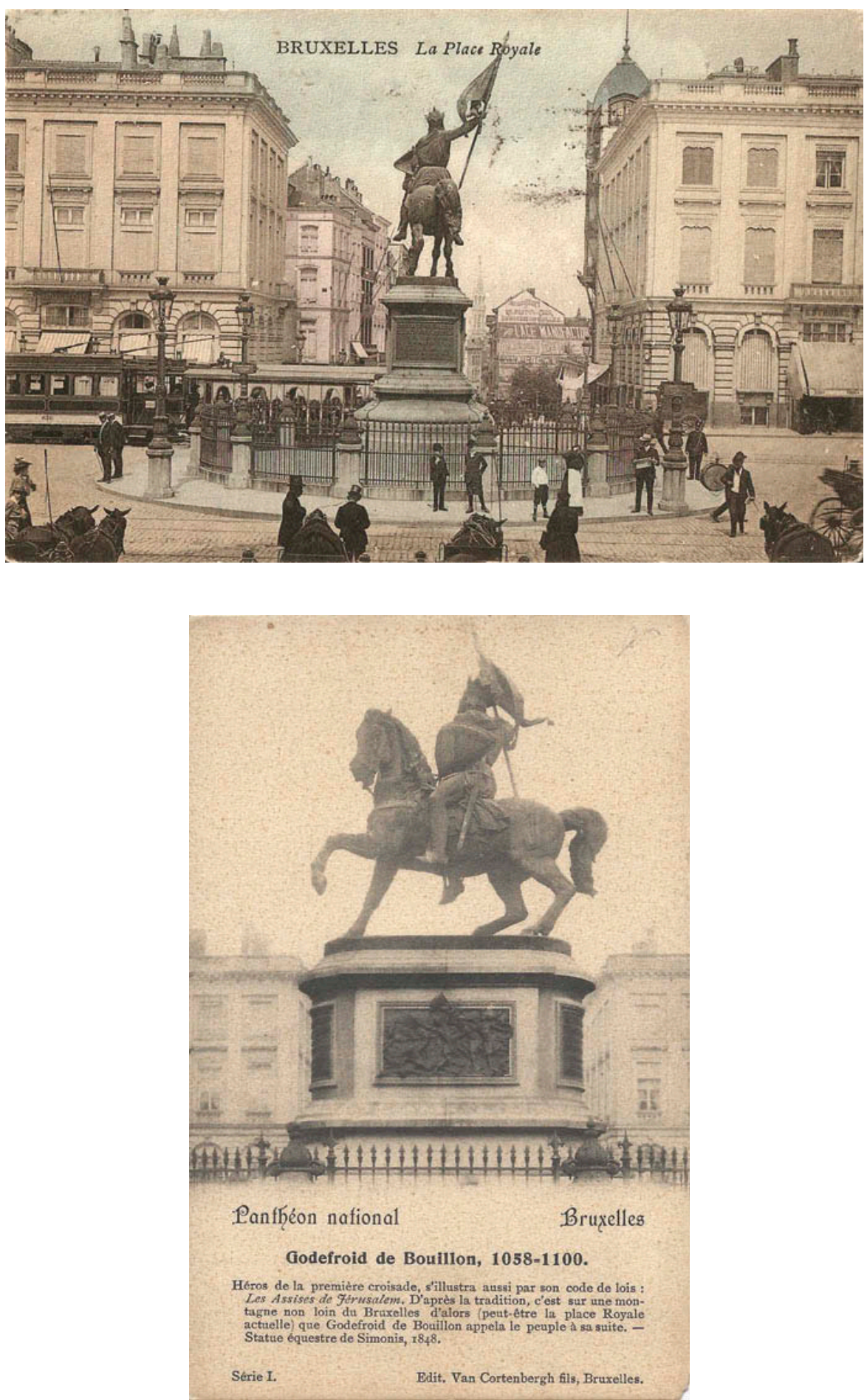

capital contributed to the promotion of a national identity and to the international distribution of a spectacular image of the city and the nation.

The most common viewpoint of picture postcards in landscape format of the statue of Godfrey of Bouillon is that taken in a northwestern direction from the steps of Coudenbergh Church, which provided a panoramic view of the lower city. Often captioned with the name of the square, these photographs depicted the monument from behind with the tower of the Town Hall in the far distance below (figure 13). On one postcard, this spectacular viewpoint is explicitly mentioned in the caption: 'Bruxelles - Place Royale (Perspective)'. Another common view of the statue includes to its right or left in the far distance the huge neoclassical Palace of Justice (1866-83), designed by the Brussels architect Joseph Poelaert, located at the 
end of the rue de la Régence/Regentschapsstraat (figure 2). These viewpoints of the equestrian statue emphasise a monumental vision of the city as a whole.

Most belle époque postcards in vertical format of the same monument, including those of foreign publishers such as Bourdier of Versailles, are captioned with the name of the statue and, on occasion, that of the sculptor. These postcards, however, are mainly taken from a different angle, with the statue viewed in the northeast direction of the Royal Park/Warandepark (figures 4, 5, 14). This viewpoint depicts the statue from the side with the horse's sculpted head turned slightly towards the camera. The monument is clearly visible in the foreground with a sharp contrast between the light background and the dark bronze of the statue. Moreover, the massive plinth with its bronze reliefs and inscriptions is displayed against the background of the rue Royale/Koningsstraat, highlighting the image's spatial depth of field. The neoclassical building façades function as a middle ground that frames the plinth and serves to enhance the depth and monumentality of the scene.

\section{Conclusion}

The picture postcards of urban statues from the belle époque examined in this essay demonstrate the preference for a monumental cityscape that glorified and legitimised the nation-state. Through a preference for views of sculpture as a grand art, serving the worship of grands hommes, these picture postcards confirmed and propagated dominant discourses on the monument and the cityscape, even as such visions were challenged in some avant-garde circles. To this effect, these commercial photographs made use of formulas, traditions and developments derived from painting and photography itself, and as such, the photography of urban statues for picture postcards can be regarded as a photographic genre in its own right. This genre is situated between documentary art reproduction practices, with its preference for plain backgrounds, and amateur photography of the city, which often emphasised the vivacity of the urban life of the statue's location. In short, the in situ photography of public sculpture lies at the intersection of studio and snapshot photography. 